\title{
EFFECTS OF ROOT HAIR LENGTH ON POTASSIUM ACQUISITION IN RICE (ORYZA SATIVA L.)
}

\author{
KLINSAWANG, S. ${ }^{1}$ - SumRANWANICH, T. ${ }^{1}-$ WANNARO, A. ${ }^{1}-$ SAENGWILAI, P. ${ }^{1,2^{*}}$ \\ ${ }^{I}$ Department of Biology, Faculty of Science, Mahidol University \\ Rama VI Road, Bangkok 10400, Thailand \\ ${ }^{2}$ Center of Excellence on Environmental Health and Toxicology (EHT) \\ Bangkok, Thailand \\ *Corresponding author \\ e-mail: patompong.sae@mahidol.edu \\ (phone: +66-9-1725-4817) \\ (Received $12^{\text {th }}$ Oct 2017; accepted $20^{\text {th }}$ Feb 2018)
}

\begin{abstract}
Potassium (K) deficiency limits rice production worldwide. It has been shown that variation in root traits, such as root hair length, influences ion uptake in many plant species. In this study, we explored natural variation of root hair length of twelve rice varieties in a roll-up system. We found a large phenotypic variation for root hair traits ranging from 0.14 to $0.21 \mathrm{~mm}$. Niaw San-pah-tawng and most upland varieties had long root hairs while lowland varieties had short root hairs. Six lowland varieties contrasting in root hair length were planted in pots under high and low K concentrations. K stress was found to decrease average biomass by $60.93 \%$ and $\mathrm{K}$ tissue content by $66 \%$. Root to shoot ratio was not affected by $\mathrm{K}$ stress. Correlation analysis indicated that long root hair was associated with reduced percentage of leaf senescence, enhanced plant biomass, and improved tissue $\mathrm{K}$ content under low $\mathrm{K}$ condition. Our results suggest that long root hair could be a useful trait for plant breeding to improve $\mathrm{K}$ acquisition in rice.
\end{abstract}

Keywords: breeding, nutrient uptake, roll up system, root traits, Thai rice

\section{Introduction}

Potassium (K) is an essential element for plant growth and yield. It has various essential functions including osmoregulation, cellular $\mathrm{pH}$ regulation, cellular ion balance, translocation of assimilates, and activation of plant enzymes (Dobermann et al., 2000 ). Rice requires at least $14.5 \mathrm{~kg}$ of $\mathrm{K}$ to produce one ton of rice grain and exceeds $200 \mathrm{~kg}$ total $\mathrm{K}$ uptake for grain yields greater than $8 \mathrm{t} \mathrm{ha}^{-1}$ (Dobermann et al., 1998; Witt et al., 1999). However, soil in major rice producing regions, such as in Cambodia, Vietnam, Laos, and the Northeast of Thailand are highly weathered acidic soils with low CEC and K reserves. Other regions, such as India and the Philippines, have soils in which $\mathrm{K}$ uptake is inhibited due to the presence of large amounts of 2:1 layer clay minerals with high K fixation capacity (Dobermann et al., 2000). These K deficient soil conditions could result in an $80 \%$ reduction of rice grain quality and yield (Slaton et al., 1995; Salim, 2002). Thus, K deficiency has become one of the major concerns for rice production (Yang et al., 2003).

With increased global rice demand, a large amount of $\mathrm{K}$ fertilizer is required to sustain rice yield. It is predicted that the global demand for potash would increase by $2.6 \%$ between 2014 to 2018, particularly in sub-Saharan Africa and Asia (FAO, 2015). Although the loss of $\mathrm{K}$ to the environment is not much of environmental concern compared to nitrogen, excessive application of $\mathrm{K}$ fertilizers to paddy fields could result in stagnant yield, decreased efficiency, and leaching of solution and exchangeable K (Islam 
et al., 2016). As an effect, the selection and development of K-efficient rice varieties is necessary to reduce $\mathrm{K}$ application rate and improve yield.

Plant root is a major organ for nutrient uptake. It has been shown that variation of root traits is associated with improved nutrient efficiency and crop production in infertile environments (Lynch, 2007). In rice, Jia et al. (2008) reported that root morphology parameters including root length, surface area, volume and count of lateral roots, as well as fine (diameter $<0.2 \mathrm{~mm}$ ) and thick (diameter $>0.2 \mathrm{~mm}$ ) roots are involved in K uptake and the translocation of $\mathrm{K}$ to shoots in hydroponics. They found that K-efficient genotypes increased fine root number by $25 \%$ when grown at moderate $\mathrm{K}$ deficient levels compared to optimal K conditions. Additionally, the K efficient genotypes had 1.3 times greater surface area, 1.4 times higher volume, and 1.5 times more root number than the inefficient rice genotypes. Among different root types, unicellular extensions of epidermal cells, or root hairs, are known to be important for water and nutrient uptake (Bates and Lynch, 2001), rhizosheath formation, and penetration of hard soil (Brown et al., 2012; Haling et al., 2013; Lynch et al., 2014). Root hair cells develop from specialized cells called trichoblasts. In many monocots including rice, trichoblasts are morphologically different from other epidermal cells before root hair initiation and alternate with atrichoblasts along longitudinal epidermal cell files (Datta et al., 211). Genotypic variation for root hair traits is evident in several crop species including wheat (Gahoonia et al., 1997), barley (Gahoonia et al., 2004), white clover (Caradus, 1981), bean (Yan et al., 1995), turf grass (Green et al., 1991), soybean (Wang et al., 2004), maize (Zhu et al., 2004) and rice (Nestler et al., 2016). Several plant species increase root hair length and density in response to suboptimal nutrient availability particularly under low $\mathrm{P}$ conditions (Ma et al., 2001; Müller et al., 2004). In most cases, plants with long root hairs are able to acquire more $\mathrm{P}$ and are better adapted in low $\mathrm{P}$ soils than those with short root hairs (Gahoonia et al., 2004).

Similar to phosphorus, $\mathrm{K}$ is relatively immobile in soil. Therefore, lengthening root hairs could possibly enhance $\mathrm{K}$ acquisition by increasing soil exploration volume and radius in the $\mathrm{K}$ depletion zone (Jungk, 2001; Rengel et al., 2008). Hogh-Jensen and Pedersen (2003) demonstrated that low K treatment affected the root morphology in pea, red clover, lucerne, barley, rye, perennial ryegrass, and oilseed rape. They found that crops altered root hair length in response to low $\mathrm{K}$ availability, and thereby maintained the uptake from sparingly soluble K sources. Furthermore, Gahoonia et al. (2006 and 2007) found that chickpea and lentil genotypes with prolific root hair formation had higher $\mathrm{K}$ shoot concentration than genotypes with shorter and less dense root hairs.

Compared to other crop species, rice root hairs and their effects for $\mathrm{K}$ uptake have been rarely investigated. In this study, we observed phenotypic variation in root hair length in twelve upland and lowland rice varieties and examined the effects of root hairs for potassium acquisition from low $\mathrm{K}$ soils in rice. We hypothesized that a large phenotypic variation of root hair length exist among Thai rice and rice varieties with long root hair length would acquire more $\mathrm{K}$ and have higher shoot mass than short haired varieties in low $\mathrm{K}$ conditions.

\section{Materials and methods}

\section{Plant materials}

Rice (Oryza sativa L.) is a member of Poaceae family. It is an annual species but may grow more than once per year under suitable conditions. Rice has round, 
hollow, jointed culms, with rather flat, sessile leaf blades, and a terminal panicle (Chang and Bardenas, 1965). Rice cultivation occurs in different types of managed ecosystems such as irrigated, rainfed upland, rainfed lowland, flood-prone systems. In this study, twelve Thai rice varieties were selected to represent varieties commonly grown in an upland (non-flooded) and lowland (flooded) system. The varieties include photoperiod sensitive lowland varieties (Khao Dawk Mali 105 (KDML105), Niaw San-pah-tawng, RD13), photoperiod insensitive lowland varieties (Phitsanulok 2, Suphan Buri 1, RD1, RD7 and RD31), photoperiod sensitive upland varieties (Goo Meuang Luang, Nam Roo and Leum Pua) and photoperiod insensitive upland varieties (R258). Seeds were obtained from the Rice Department of the Ministry of Agriculture and Cooperatives of Thailand.

\section{Growth conditions}

\section{Roll-up system}

Seeds of the twelve rice varieties were surface sterilized for 1 min in $10 \% \mathrm{NaOCl}$ and washed three times in deionized water before germination. The experiment was arranged in a randomized complete block design with three replications. In each replicate, ten seeds per variety were randomly selected and wrapped in brown germination paper in the form of a cigar roll. The rolls were then soaked in a 0.5 $\mathrm{mM} \mathrm{CaSO} 4.2 \mathrm{H}_{2} \mathrm{O}$ solution. Seedlings were germinated in darkness at $28 \pm 1{ }^{\circ} \mathrm{C}$ in a chamber for 3 days, then placed under a photoperiod of 14:10 h supplemented with photosynthetically active radiation at $0.18 \mathrm{mmol}$ photons $\mathrm{m}^{-2} \mathrm{~s}^{-1}$. Seven days after germination, primary roots of three seedlings for each replication were harvested and preserved in $75 \%$ ethanol.

\section{Greenhouse system}

Six lowland rice varieties including Phitsanulok 2, RD7, Niaw San-pah-tawng, Suphan Buri 1, RD1, and RD13 were planted in greenhouse pots to examine the effect of root hair length on potassium acquisition. Plants were grown in the greenhouse located on the campus of Mahidol University, Thailand $13^{\circ} 45^{\prime} 55.4^{\prime \prime} \mathrm{N}$ $100^{\circ} 31^{\prime} 34.4^{\prime \prime} \mathrm{E}$. The average ambient temperature during the study was $28.5 \pm 1.2$ ${ }^{\circ} \mathrm{C}$. The seeds of six selected lowland rice varieties were germinated in sand media for 15 days, then the seedlings were transplanted into pots $25 \mathrm{~cm}$ in diameter and 23 $\mathrm{cm}$ in height. The growth medium consisted of a mixture (volume based) of $10 \%$ clay soil and $90 \%$ acid washed sand. One day before planting, the pots were saturated with $2 \mathrm{~L}$ of modified Yoshida solution (Yoshida et al., 1976) adjusted to $\mathrm{pH}$ 5. The nutrient solution for the high $\mathrm{K}$ treatment consisted of $1.5 \mathrm{mM} \mathrm{NH}_{4} \mathrm{NO}_{3}$, $0.3 \mathrm{mM} \mathrm{NaH} \mathrm{PO}_{4} \mathrm{H}_{2} \mathrm{O}, 0.5 \mathrm{mM} \mathrm{K} \mathrm{SO}_{4}, 1 \mathrm{mM} \mathrm{CaCl}{ }_{2} .2 \mathrm{H}_{2} \mathrm{O}, 1.5 \mathrm{mM} \mathrm{MgSO} \mathrm{Mg}_{4} .7 \mathrm{H}_{2} \mathrm{O}$, $0.00007 \mathrm{mM}\left(\mathrm{NH}_{4}\right)_{6} \mathrm{Mo}_{7} \mathrm{O}_{24} .4 \mathrm{H}_{2} \mathrm{O}, 0.02 \mathrm{mM} \mathrm{H}_{3} \mathrm{BO}_{3}, 0.00015 \mathrm{mM} \mathrm{ZnSO} .7 \mathrm{H}_{2} \mathrm{O}$, $0.0002 \mathrm{mM} \mathrm{CuSO} 4.5 \mathrm{H}_{2} \mathrm{O}, 0.035 \mathrm{mM} \mathrm{FeCl}_{3} .6 \mathrm{H}_{2} \mathrm{O}, 0.07 \mathrm{mM} \mathrm{C}_{6} \mathrm{H}_{8} \mathrm{O}_{7} . \mathrm{H}_{2} \mathrm{O}, 0.0625$ $\mathrm{mM} \mathrm{H} \mathrm{SO}_{4}, 0.009 \mathrm{mM} \mathrm{MnSO} \cdot \mathrm{H}_{2} \mathrm{O}$. Initially, the low $\mathrm{K}$ treatment received $90 \%$ less $\mathrm{K}$ than the high $\mathrm{K}$ treatment. After the initial treatment, $\mathrm{K}$ was completely withdrawn from the nutrient solution. $\mathrm{CaSO}_{4}$ was used to substitute for sulfate in the low K treatments. Plants were fertigated every other day with $100 \mathrm{ml}$ of deionized water alternating with nutrient solutions. The experiment was arranged in a randomized complete block design with four replications. Blue and yellow sticky 
insect traps were placed around and above the planting areas for pest control. No pesticide was applied. The plants were harvested 2 months after being transplanted.

\section{Shoot and root harvest}

At harvest, shoot height, tiller number, and the percentage of leaf senescence were measured prior to root harvest. The root system was carefully removed from the growth media and washed with tap water. Root traits including crown root number and maximum rooting depth were evaluated (Vejchasarn et al., 2016). Crown root number was manually counted. Rooting depth was determined by measuring the length of the root system after being excavated from the pot. Three crown roots for each variety replication were separated and preserved in $75 \% \mathrm{EtOH}$ for root hair analysis. Finally, the plant shoot and root were dried at $60{ }^{\circ} \mathrm{C}$ for 3 days before assessing the dry weight.

\section{Root hair measurement}

Three representative root segments were selected from primary and crown roots of an individual plant. The roots were stained with $0.05 \%$ toluidine blue and carefully rinsed in deionized water prior to root hair examination. Root hairs were stained pinkish-blue whereas root surface remained unstained allowing for a clear observation of root hairs. For determination of root hair length, the stained roots were observed at 40× magnification under a Macro zoom imaging system (MVX10) consisting of a dissecting microscope equipped with a camera (Olympus, Tokyo, Japan). A section of the root with consistent fully elongated hairs was selected for image capture. Root hair length was quantified using a line tool in ImageJ version 1.47 (Abràmoff et al., 2004). Five representative hairs per image were selected for length measurement. Root hair length was calculated by comparing the number of pixels of a root hair to the number of pixels per $\mathrm{mm}$ obtained from an image of a micrometer scale taken at the same magnification (650 pixels $\mathrm{mm}^{-1}$ ).

\section{Potassium analysis}

Dried plant samples were first grounded with a mortar. Then, five hundred milligrams of fine samples were processed through acid digestion in an opened container as described by Simmons et al. (2015). Samples were heated at $100{ }^{\circ} \mathrm{C}$ for $30 \mathrm{~min}$ in a block heater with $6 \mathrm{ml}$ of $2: 1\left(\mathrm{HNO}_{3}: \mathrm{HClO}_{4}\right)$. The temperature was then increased to $150{ }^{\circ} \mathrm{C}$ until the solution became yellow and transparent. Once the solution changed color, $1 \mathrm{~mL}$ hydrochloric acid was added and the temperature was increased to $160{ }^{\circ} \mathrm{C}$ for $30 \mathrm{~min}$. After, the samples were cooled, filtered with Whatman No.42 filtered paper, and adjusted to $25 \mathrm{~mL}$ with $1 \% \mathrm{HNO}_{3}$. The potassium concentration of the samples were then determined using the Flame Atomic Absorption Spectrophotometer (Perkin Elmer) (Simmons et al., 2015).

\section{Statistical analysis}

Statistical analyses were performed using $\mathrm{R}$ version 3.1.3. Linear mixed effect models were developed using the lmer function from the package lme4 (Bates et al., 2014). Correlation analyses were performed on individual plant data as well as the mean values of the measurements taken per genotype for percentage of biomass and $\mathrm{K}$ content reduction. 


\section{Results}

\section{Natural variation in root hair length among lowland and upland rice varieties}

There was significant phenotypic variation in root hair length among 12 Thai rice varieties grown in the roll-up system (Fig. 1). Root hair length in lowland rice varieties ranged from 0.14 to $0.21 \mathrm{~mm}$ and upland rice varieties ranged from 0.16 to $0.19 \mathrm{~mm}$ (Fig. 1). Niaw San-pah-tawng, R258, and Goo Meuang Luang had the longest root hairs while RD1, Suphan Buri 1, and Leum Pua had the shortest root hairs.

a)
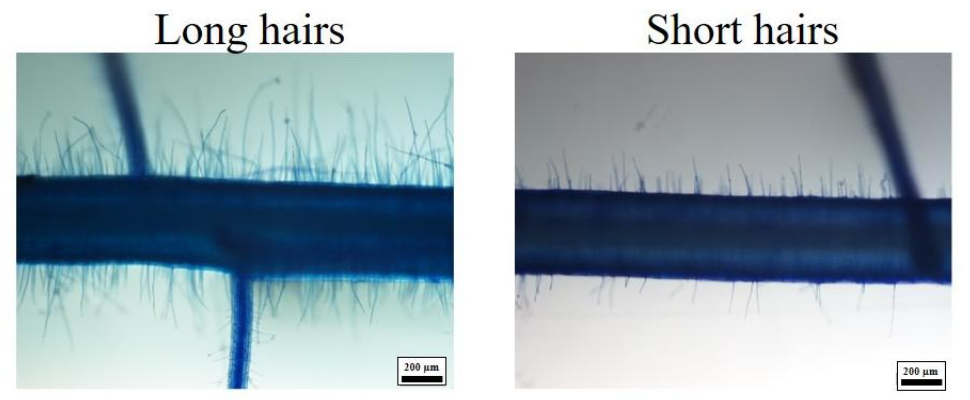

b)

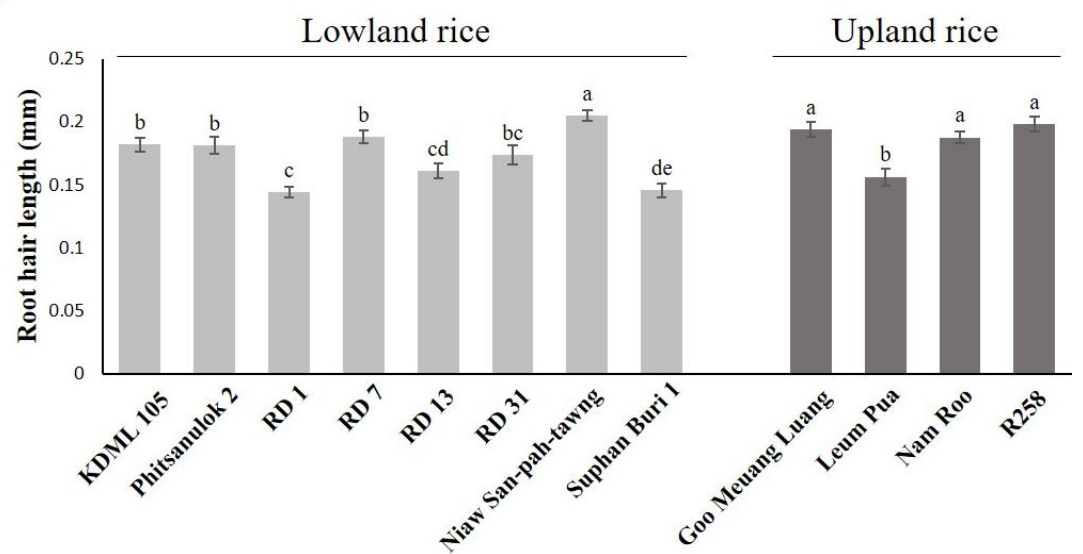

Figure 1. Root hair length among rice varieties a) images of long and short root hairs observed in this study b) variation of root hair length among lowland and upland rice. Plants were harvested at 7 days after planting in a roll up system. Different letters indicate significant difference at $p<0.05$

\section{Effects of low K availability on root hair length, plant growth, and tissue K content}

Low $\mathrm{K}$ availability did not affect the average root hair length, tiller number, percentage of leaf senescence, crown root number, rooting depth, and root to shoot ratio (Table 1). However, shoot, root, and total dry weight was significantly reduced by $49 \%$, $27 \%$ and $42 \%$, respectively. In addition, tissue $\mathrm{K}$ content in shoot, root, and whole plants were reduced by $37 \%, 28 \%$ and $33 \%$, respectively (Table 1). We found that root hair length was consistent among varieties and did not significantly respond to $\mathrm{K}$ stresses (Fig. 2a). Among the varieties, Phitsanulok 2 had long root hair while RD7 and RD13 had short root hair length in both treatments. Under high K availability, total dry weight was similar among varieties except for RD7 which had slightly lower biomass than the others (Fig. 2c). The plant's K contents were significantly different among varieties(Fig. $2 b)$. In addition, total dry weight and plant's $\mathrm{K}$ content of all 6 varieties were substantially reduced under low K conditions (Fig. $2 b$ and $c$ ). 
Table 1. Effects of suboptimal potassium conditions on an average plant growth and $K$ content. NS, non-statistical significant at $p<0.05$

\begin{tabular}{c|c|c|c}
\hline Parameter & High K & Low K & Significance \\
\hline Root hair length, mm & $0.139 \pm 0.01$ & $0.137 \pm 0.01$ & NS \\
Tiller number & $8.70 \pm 0.68$ & $6.91 \pm 0.76$ & NS \\
Leaf senescence, \% & $25.36 \pm 1.94$ & $35.66 \pm 4.99$ & NS \\
Crown root number & $68.55 \pm 17.99$ & $63.04 \pm 19.99$ & NS \\
Lateral root branching & $12.15 \pm 0.65$ & $11.51 \pm 0.62$ & NS \\
Rooting depth, cm & $28.89 \pm 1.86$ & $24.30 \pm 1.78$ & NS \\
Shoot dry weight, g & $13.00 \pm 0.37$ & $6.37 \pm 0.61$ & p $<0.001$ \\
Root dry weight, g $^{\text {Total dry weight, g }}$ & $7.86 \pm 0.19$ & $2.11 \pm 0.31$ & p $<0.001$ \\
Shoot K content, mg plant ${ }^{-1}$ & $20.02 \pm 0.74$ & $8.47 \pm 0.87$ & p $<0.001$ \\
Root K content, mg plant $^{-1}$ & $44.44 \pm 3.36$ & $16.29 \pm 2.09$ & p $<0.001$ \\
Total K content, mg plant $^{-1}$ & $29.74 \pm 2.66$ & $8.31 \pm 1.27$ & p $<0.001$ \\
Root to shoot ratio & $74.17 \pm 4.80$ & $24.61 \pm 3.26$ & $\mathrm{p}<0.001$ \\
\hline
\end{tabular}

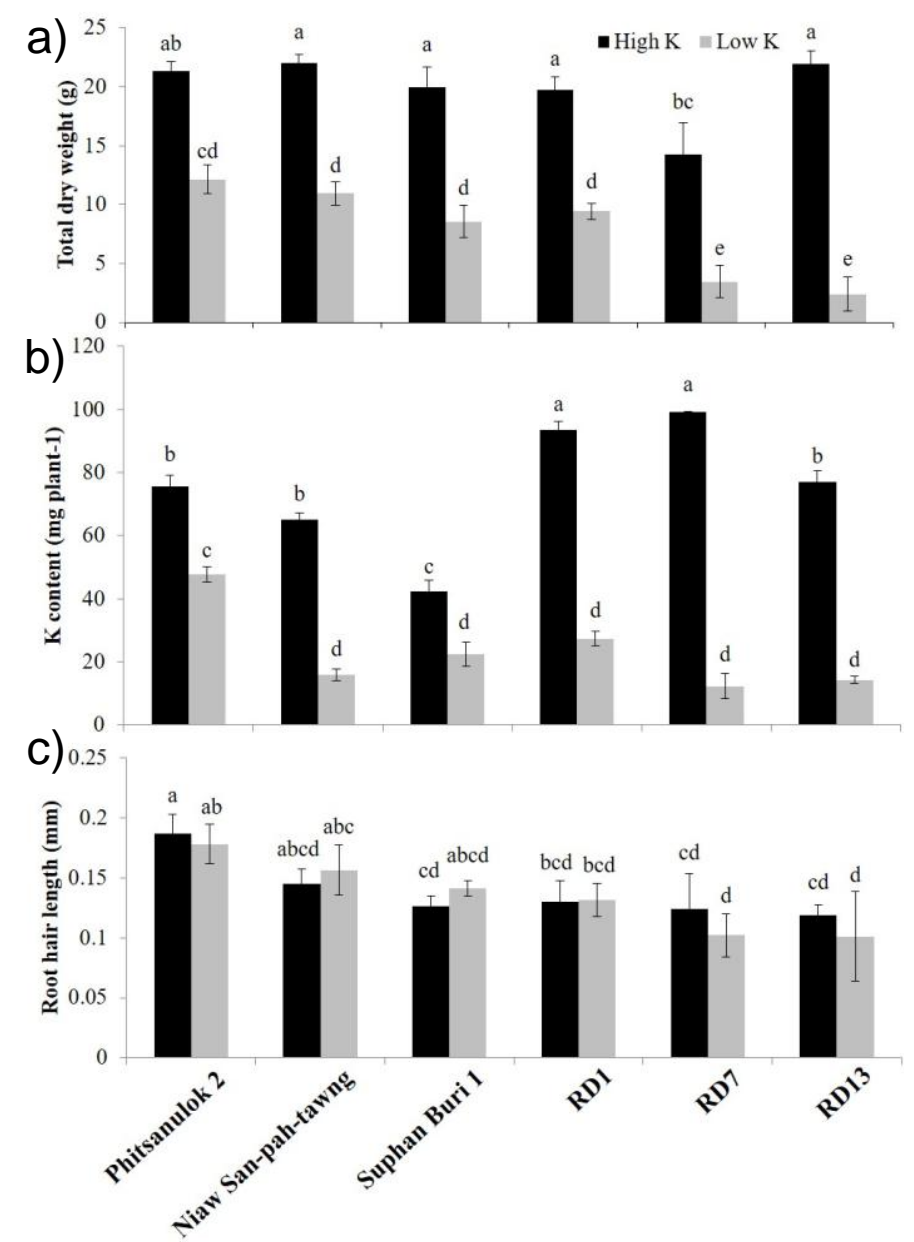

Figure 2. Bar graphs showing a) total dry weight b) potassium content and c) root hair length of six lowland rice varieties under low and optimal $K$ conditions. Plants were harvested 2 months after planting. Different letters indicate significant difference at $p<0.05$ 


\section{Correlation analysis}

Correlation analysis between root hair length, shoot, and root traits indicate that root hair length was negatively correlated with the percentage of leaf senescence $(r=-0.74)$, positively correlated with plant growth $(\mathrm{r}=0.62)$ and $\mathrm{K}$ accumulation $(\mathrm{r}=0.61)$ under low $\mathrm{K}$ conditions (Table 2). There was no significant correlation between root hair length, crown root number, lateral root branching, and rooting depth under both high and low $\mathrm{K}$ conditions suggesting that root hair length is independent from these root traits (Table 2). In addition, increased root hair length was associated with high relative biomass $(\mathrm{r}=0.93, \mathrm{p}<0.01)$ and $\mathrm{K}$ content $(\mathrm{r}=0.81, \mathrm{p}<0.05)$ when compared between low $\mathrm{K}$ and optimal K conditions (Fig. 3).

Table 2. Correlation coefficient between root hair length and shoot and root parameters under high and low $K$ conditions measured in pot of 6 Thai rice varieties. *, **, *** denote significance at $p<0.05, p<0.01$, and $p<0.001$, respectively

\begin{tabular}{c|c|c}
\hline Parameter & High K & Low K \\
\hline Tiller number & $0.48^{*}$ & $0.69^{* *}$ \\
Leaf senescence, \% & -0.22 & $-0.74^{* * *}$ \\
Crown root number & 0.33 & 0.41 \\
Lateral root branching & 0.12 & 0.33 \\
Rooting depth, cm & 0.34 & 0.63 \\
Shoot dry weight, g & 0.25 & $0.59^{* *}$ \\
Root dry weight, g & 0.29 & $0.55^{* *}$ \\
Total dry weight, g & 0.42 & $0.62^{* *}$ \\
Shoot K content, mg plant ${ }^{-1}$ & $0.51 *$ & $0.59^{* *}$ \\
Root K content, mg plant ${ }^{-1}$ & 0.01 & $0.60^{* *}$ \\
Total K content, mg plant & & $0.61 * *$ \\
Root to shoot ratio & 0.36 & $0.44^{*}$ \\
\hline
\end{tabular}

\section{Discussion}

In this study, a large phenotypic variation of root hair length was found for twelve Thai rice varieties in a roll-up system (Fig. 1). Root hair length ranged between 0.14 to $0.21 \mathrm{~mm}$, a typical range reported by other studies (Fig. 1). Compared to other crop species, such as wheat and maize (Zhu et al., 2005; Delhaize et al., 2015), rice root hair length has a much shorter range. Among rice varieties, we found that majority of upland varieties had long root hairs. This is not surprising because soils in upland fields are largely affected by suboptimal nutrient availability as nutrients often react with ions, such as iron, aluminum, and calcium found in soil, which leads to the formation of low mobile complexes when compared to those in rain-fed lowlands (Holford, 1997). Therefore, long root hairs found in these varieties could be one of the adaptive strategies for growing in such an environment.

It has been shown that several plant species increase root hair length in response to low K availability (Hogh-Jensen and Pedersen, 2003). In this study, we found that root hair length of all six rice varieties was not affected by suboptimal $\mathrm{K}$ conditions and plasticity for root hair length is not a universal trait but rather species- and genotypespecific. Additionally, long root hair was found to be associated with increased biomass and $\mathrm{K}$ content under low $\mathrm{K}$ conditions. In paddy environments, the depletion of readily 
available $\mathrm{K}$ and exchangeable $\mathrm{K}$ in the rhizosphere could extend over $10 \mathrm{~mm}$ from the root surface at both the low and adequate $\mathrm{K}$ conditions (Yang et al., 2005). The results were consistent with Shi et al. (2004) research in which they reported the same range of the depletion zone of extractable $\mathrm{K}$ around the root $(10 \mathrm{~cm})$ in several plant species. Considering the effective the diffusion coefficient of $\mathrm{K}$ in soil which is approximately two orders of magnitude higher than that of $\mathrm{P}$, the depletion zone of $\mathrm{K}$ around the root should be much smaller than that of P. Interestingly, Shi et al. (2004) found that the depletion range was even wider than that of the available $\mathrm{P}$ in the same experiment, thus, the depletion zone around a root is not only influenced by the effective diffusion of the nutrients but also the demand of the plants and possibly the concentrations of the nutrients in the soil. Our results support the hypothesis that long root hair may improve $\mathrm{K}$ acquisition in low $\mathrm{K}$ soils by increasing root surface area and decreasing the distance to the source of $\mathrm{K}$, which enhances the volume of soil exploration beyond the $\mathrm{K}$ depletion zone.

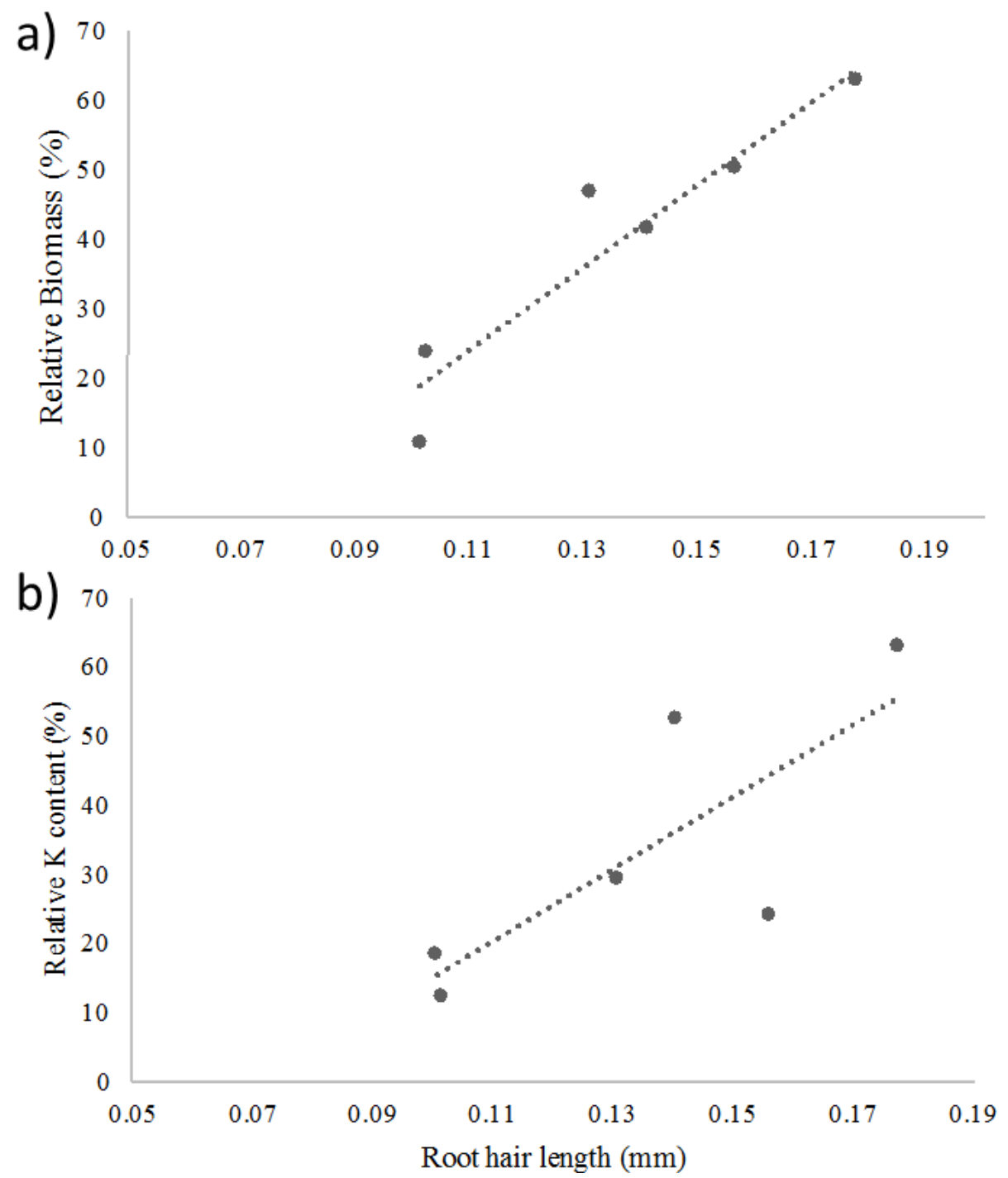

Figure 3. Correlation analysis between root hair length and relative a) biomass $(r=0.93$, $p<0.01)$ and b) K content $(r=0.81, p<0.05)$ compared between low $K$ and optimal $K$ conditions 
A high root to shoot ratio is characteristically associated with plants growing in infertile soils (Wang and Yang, 2003). In this study, we found that root to shoot ratio was not significantly affected by low $\mathrm{K}$ availability. It has been suggested that root growth in potassium-deficient plants was more carbon limited when compared to plants with other deficiencies such as phosphorus and nitrogen. Limited carbon is largely due to a strong reduction in photosynthesis and the lack of an adaptive response in carbon allocation between roots and shoots. Thus, plants in $\mathrm{K}$ deficient conditions do not allocate more carbon to the root system (Postma et al., 2011; Miguel et al., 2015).

Several lines of evidence suggest that root traits, such as root number and root branching, influence $\mathrm{K}$ uptake (Yang et al., 2003). In our study, the selected rice varieties had comparable root number and branching (Fig. 4). In addition, we found that $\mathrm{K}$ stress did not affect average values of these root traits. Therefore, we conclude that the enhanced $\mathrm{K}$ uptake in the low $\mathrm{K}$ environment was attributable to the benefit of long root hair length.

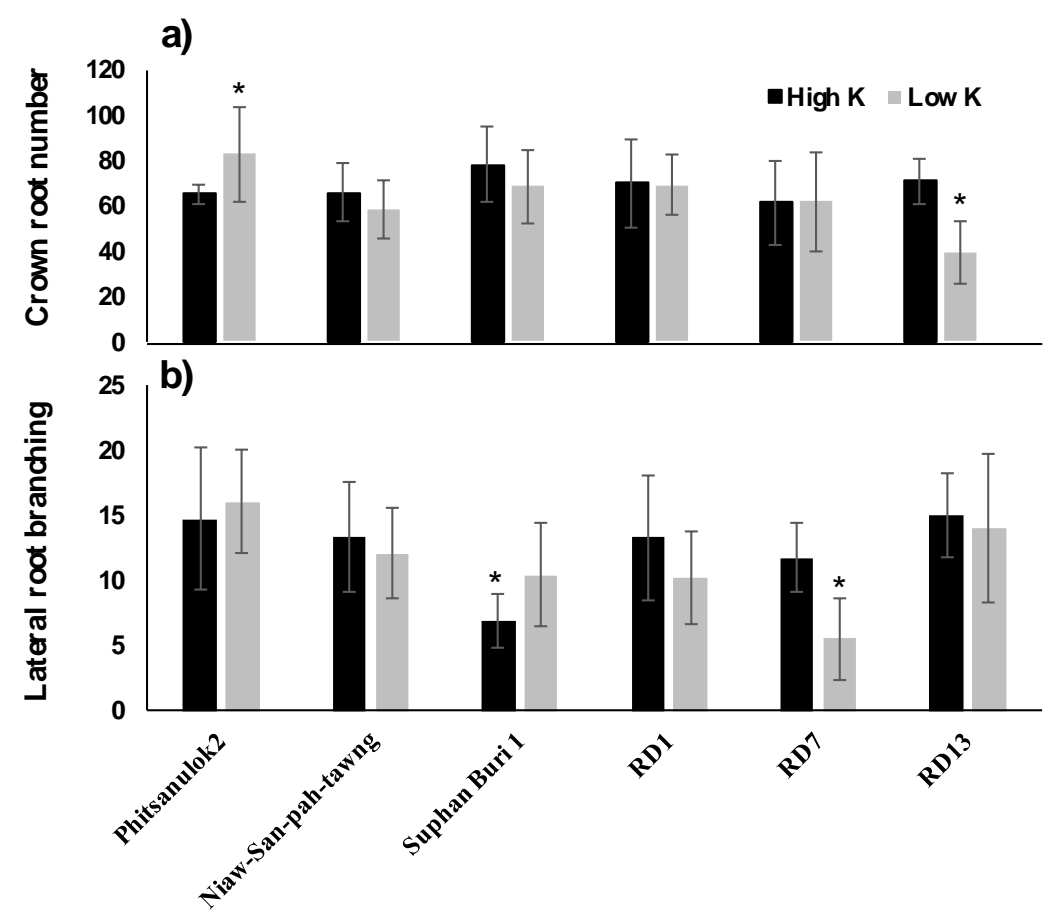

Figure 4. Bar graphs showing a) crown root number and b) lateral root number of six lowland rice varieties under low and optimal $K$ conditions. Plants were harvested at 2 months after planting. ${ }^{*}$ indicates significant difference at $p<0.05$

Genetic studies in crop species including maize (Zhu et al., 2005), wheat (Horn et al., 2016), and common bean (Yan et al., 2004) indicate that root hair length is a complex quantitative trait and is controlled by a number of quantitative trait loci (QTLs). In rice, QTLs associated with variation of root hair length have not yet been identified. However molecular studies have shown that root hair elongation in rice is largely controlled by $O S A P Y$ gene encoding an enzyme apyrase, which catalyses the hydrolysis of phosphoanhydride bonds of nucleoside tri- and di-phosphates into mono-phosphates (Yuo et al., 2009). The development of molecular markers associated with root hair traits in rice is currently carried out to enhance efficiency of rice breeding program. 


\section{Conclusions}

Our study shows that phenotypic variation in root hair length exists among upland and lowland Thai rice varieties. In addition, long root hair was associated with enhanced plant biomass and improved tissue $\mathrm{K}$ content under low $\mathrm{K}$ conditions. Further experiments in farmers' fields are underway to validate the physiological utility of root hair length for $\mathrm{K}$ acquisition in agronomic settings. For breeding perspectives, we see ample opportunity for using rice in Thai germplasms, particularly, Niaw San-pah-tawng and Pitsanulok2 which consistently had long root hairs across the growing systems, as donors for long root hairs. Furthermore, the development of high-throughput phenotyping approaches and molecular markers associated with long root hairs will help enhance efficiency and effectiveness of breeding programs targeting root hair length in rice.

Acknowledgements. This research project is supported by Mahidol University.

\section{REFERENCES}

[1] Abràmoff, M. D., Magalhães, P. J., Ram, S. J. (2004): Image processing with ImageJ. Biophotonics International 11: 36-42.

[2] Bates, D., Mächler, M., Bolker, B., Walker, S. (2014): Fitting linear mixed-effects models using lme4. - Journal of Statistical Software 67: 1-48.

[3] Bates, T. R., Lynch, J. P. (2001): Root hairs confer a competitive advantage under low phosphorus availability. - Plant and Soil 236: 243-250.

[4] Brown, L. K., George, T. S., Thompson, J. A., Wright, G., Lyon, J., Dupuy, L., Hubbard, S. F., White, P. J. (2012): What are the implications of variation in root hair length on tolerance to phosphorus deficiency in combination with water stress in barley (Hordeum vulgare)? - Annals of Botany 110: 319-328.

[5] Caradus, J. R. (1981): Effect of root hair length on white clover growth over a range of soil phosphorus levels. - New Zealand Journal of Agricultural Research 24: 353-358.

[6] Chang, T. T., Bardenas, E. A. (1965): The Morphology and Varietal Characteristics of the Rice Plant. Technical Bulletin, pp. 3-4. - IRRI, Los Banos.

[7] Datta, S., Kim, C. M., Pernas, M., Pires, N. D., Proust, H., Tam, T., Vijayakumar, P. Dolan, L. (2011): Root hairs: development, growth and evolution at the plant-soil interface. - Plant and Soil 346: 1-14.

[8] Delhaize, E., Rathjen, T. M., Cavanagh, C. R. (2015): The genetics of rhizosheath size in a multiparent mapping population of wheat. - Journal of Experimental Botany 66: 4527-4536.

[9] Dobermann, A., Fairhurst, T. (2000): Rice: Nutrient Disorders \& Nutrient Management. Handbook Series, Potash \& Phosphate Institute (PPI). - Potash \& Phosphate Institute of Canada (PPIC), Norcross and International Rice Research Institute, Los Banos.

[10] Dobermann, A., Cassman, K. G., Mamaril, C. P., Sheehy, J. E. (1998): Management of phosphorus, potassium, and sulfur in intensive, irrigated lowland rice. - Field Crops Research 56: 113-138.

[11] FAO (2015): "World Fertilizer Trends and Outlook to 2018." - Food and Agriculture Organization of the United Nations (FAO), Rome.

[12] Gahoonia, T. S., Nielsen, N. E. (2004): Barley genotypes with long root hairs sustain high grain yields in low-P field. - Plant and Soil 262: 55-62.

[13] Gahoonia, T. S., Care, D., Nielsen, N. E. (1997): Root hairs and phosphorus acquisition of wheat and barley cultivars. - Plant and Soil 191: 181-188. 
[14] Gahoonia, T. S., Ali, O., Sarker, A. (2006): Genetic variation in root traits and nutrient acquisition of lentil genotypes. - Journal of Plant Nutrition 29: 643-655.

[15] Gahoonia, T. S., Ali, R., Malhotra, R. S. (2007): Variation in root morphological and physiological traits and nutrient uptake of chickpea genotypes. - Journal of Plant Nutrition 30: 829-841.

[16] Green, R. L., Beard, J. B., Oprisko, M. J. (1991): Root hairs and root lengths in nine warm-season turfgrass genotypes. - Journal of the American Society for Horticultural Science 116: 965-969.

[17] Haling, R. E., Brown, L. K., Bengough, A. G., Young, I. M., Hallett, P. D., White, P. J., George, T. S. (2013): Root hairs improve root penetration, root - soil contact, and phosphorus acquisition in soils of different strength. - Journal of Experimental Botany 64: 3711-3721.

[18] Hofer, R. M. (1991): Root Hairs. - In: Waisel, Y., Eshel, A., Kafkafi, U. (eds.) Plant Roots - The Hidden Half, pp. 129-148. Marcel Dekker, New York.

[19] Hogh-Jensen, H., Pedersen, M. B. (2003): Morphological plasticity by crop plants and their potassium use efficiency. - Journal of Plant Nutrition 26: 969-984.

[20] Horn, R., Wingen, L. U., Snape, J. W., Dolan, L. (2016): Mapping of quantitative trait loci for root hair length in wheat identifies loci that co-locate with loci for yield components. - Journal of Experimental Botany 67: 4535-4543.

[21] Islam, A., Saha, P. K., Biswas, J. C., Saleque, M. A. (2016): Potassium fertilization in intensive wetland rice system : yield, potassium use efficiency and soil potassium status. - International Journal of Agricultural Papers 1: 7-21.

[22] Jia, Y., Yang, X., Feng, Y., Jilani, G. (2008): Differential response of root morphology to potassium deficient stress among rice genotypes varying in potassium efficiency. Journal of Zhejiang University Science 9: 427-434.

[23] Jungk, A. (2001): Root hairs and the acquisition of plant nutrients from soil. - Journal of Plant Nutrition and Soil Science 164: 121-129.

[24] Lynch, J. P. (2007): Roots of the second green revolution. - Australian Journal of Botany 55: 493-512.

[25] Lynch, J. P., Brown, K. M. (2001): Topsoil foraging - an architectural adaptation of plants to low phosphorus availability. - Plant Soil 237: 225-237.

[26] Lynch, J. P., Chimungu, J. G., Brown, K. M. (2014): Root anatomical phenes associated with water acquisition from drying soil: targets for crop improvement. - Journal of Experimental Botany 65: 6155-6166.

[27] Ma, Z., Bielenberg, D. G., Brown, K. M., Lynch, J. P. (2001): Regulation of root hair density by phosphorus availability in Arabidopsis thaliana. - Plant, Cell and Environment 24: 459-467.

[28] Miguel, M. A., Postma, J. A., Lynch, J. P. (2015): Phene synergism between root hair length and basal root growth angle for phosphorus acquisition. - Plant Physiology 175: 1430-1439.

[29] Müller, M., Schmidt, W. (2004): Environmentally induced plasticity of root hair development in Arabidopsis. - Plant Physiology 134: 409-419.

[30] Nestler, J., Keyes, S. D., Wissuwa, M. (2016): Root hair formation in rice (Oryza sativa L.) differs between root types and is altered in artificial growth conditions. - Journal of Experimental Botany 67: 3699-3708.

[31] Postma, J. A., Lynch, J. P. (2011): Root cortical aerenchyma enhances the growth of maize on soils with suboptimal availability of nitrogen, phosphorus, and potassium. Plant Physiology 156: 1190-1201. 
[32] Rengel, Z., Damon, P. M. (2008): Crops and genotypes differ in efficiency of potassium uptake and use. - Physiologia Plantarum 133: 624-636.

[33] Salim, M. (2002): Effects of K nutirition on growth, biomass and chemical composition of rice plants and host-insect interaction. - Pakistan Journal of Agricultural Research 17: $14-21$.

[34] Shi, W., Wang, X., Yan, W. (2004): Distribution patterns of available P and K in rape rhizosphere in relation to genotypic difference. - Plant and Soil 261: 11-16.

[35] Simmons, R. W., Chaney, R. L., Angle, J. S., Kruatrachue, M., Klinphoklap, S., Reeves, R. D., Bellamy, P. (2015): Towards practical cadmium phytoextraction with N. occaea Caerulescens. - International Journal of Phytoremediation 17: 191-199.

[36] Slaton, N. A., Cartwright, R. D., Wilson, C. E. (1995): Potassium deficiency and plant diseases observed in rice fields. - Better Crops: 12-14.

[37] Suzuki, N., Taketa, S., Ichii, M. (2003): Morphological and physiological characteristics of a root-hairless mutant in rice (Oryza sativa L.). - Plant Soil 101: 9-17.

[38] Vejchasarn, P., Lynch, J. P., Brown, K. M. (2016): Genetic variability in phosphorus responses of rice root phenotypes. - Rice 9: 29.

[39] Wang, L., Liao, H., Yan, X., Zhuang, B., Dong, Y. (2004): Genetic variability for root hair traits as related to phosphorus status in soybean. - Plant and Soil 261: 77-84.

[40] Witt, C., Dobermann, A., Abdulrachman, S., Gines, H., Guanghuo, W., Nagarajan, R., Satawatananont, S., Son, T. T., Tan, P. S., Simbahan, G. (1999): Internal nutrient efficiencies of irrigated lowland rice in tropical and subtropical Asia. - Field Crops Research 63: 113-138.

[41] Yan, X., Beebe, S. E., Lynch, J. P. (1995): Genetic variation for phosphorus efficiency of common bean in contrasting soil types: II. Yield response. - Crop Science 35: 1094-1099.

[42] Yan, X., Liao, H., Beebe, S. E., Blair, M. W., Lynch, J. (2004): QTL mapping of root hair and acid exudation traits and their relationship to phosphorus uptake in common bean. - Plant and Soil 265: 17-29.

[43] Yang, X. E., Liu, J. X., Wang, W. M., Li, H., Luo, A. C., Ye, Z. Q., Yang, Y. (2003): Genotypic differences and some associated plant traits in potassium internal use efficiency of lowland rice (Oryza sativa L.). - Nutrient Cycling in Agroecosystems 67: 273-282.

[44] Yang, X. E., Li, H., Kirk, G. J. D. (2005): Room - induced changes of potassium in the rhizosphere of low land rice. - Communications in Soil Science and Plant Analysis 36: 1947-1963.

[45] Yoshida, S., Forno, D. A., Cock, J. H., Gomez, K. A. (1976): Laboratory Manual for Physiological Studies of Rice, pp. 61-67. - International Rice Research Institute, Philippines.

[46] Yu, Z., Kang, B., He, X., Lv, S., Bai, Y., Ding, W., Chen, M., Cho, H. T., Wu, P. (2011): Root hair-specific expansins modulate root hair elongation in rice. - The Plant Journal 66: 725-734.

[47] Yuo, T., Toyota, M., Ichii, M., Taketa, S. (2009): Molecular cloning of a root hairless gene $r$ thl in rice. - Breeding Science 59: 13-20.

[48] Zhu, J., Lynch, J. P. (2004): The contribution of lateral rooting to phosphorus acquisition efficiency in maize (Zea may) seedlings. - Functional Plant Biology 31: 949-958.

[49] Zhu, J., Kaeppler, S. M., Lynch, J. P. (2005): Mapping of QTL controlling root hair length in maize (Zea mays L.) under phosphorus deficiency. - Plant and Soil 270: 299-310. 